\title{
Effect of Sodium Dodecyl Sulphate on the Composition of Electroless Nickel-Yttria Stabilized Zirconia Coatings
}

\author{
Nkem O. Nwosu, Alan M. Davidson, Colin S. Hindle \\ School of Engineering and the Built Environment, Edinburgh Napier University, Edinburgh, UK \\ E-mail: \{n.nwosu, a.davidson, c.hindle\}@napier.ac.uk \\ Received June 1, 2011; revised June 27, 2011; accepted July 5, 2011
}

\begin{abstract}
The influence of a surfactant on the composition of nickel—yttria stabilised zirconia (YSZ) cermet coatings, applied by electroless nickel plating technique was examined. The amphiphilic characteristics of anionic surfactant sodium dodecyl sulphate (SDS), was relied upon for enhanced dispersion of YSZ particles co-deposited for use as anodes in solid oxide fuel cell technology and potential heat absorbing layers in thermal barrier coatings. Optical microscopy was employed to study the correlation between the plating thickness, level of ceramic loading and SDS concentration while the effect of the surfactant and fineness of YSZ particles on the as-deposited coating's ceramic to metal ratio, was analysed using energy dispersive $\mathrm{X}$-ray analysis (EDXA) characterisation technique.
\end{abstract}

Keywords: Electroless Nickel Composite Coatings, Solid Oxide Fuel Cell Anodes, Coating Composition, Additives

\section{Introduction}

Electroless nickel plating (ENP) is a highly desirable surface coating technique that has the capability of producing uniform surface deposits regardless of recesses and bores [1]. Although Brenner \& Riddell are credited with developing the process [1,2], Odekerken who while attempting to improve the corrosion resistance of nickel chromium electrodeposits, applied an intermediate layer of alumina $\left(\mathrm{Al}_{2} \mathrm{O}_{3}\right)$ and poly vinyl chloride (PVC) within a metal matrix, is widely acknowledged as the earliest demonstrator of particulate matter incorporation by ENP $[3,4]$. Since then, numerous studies such as those of Sheela \& Pushpavanam [5] who adopted the technique to synthesise high wear resistant diamond-nickel composite coatings, have been carried out to establish potential applications for the technology.

Recently, Davidson \& Waugh [6] successfully applied ENP to the manufacture of nickel-yttria stabilised zirconia cermet coatings for use as solid oxide fuel cell (SOFC) electrodes. This was called electroless co-deposition (ECD) of nickel and ceramic. Simply requiring a source of energy to liberate chelated metal ions maintained in suspension by complexing agents, the technique has been shown to have a much faster rate of production and lower energy consumption than traditional SOFC electrode manufacturing techniques such as silk screening and tape casting [7]. It's non-requirement of a high energy sintering stage, offers an opportunity for cost reduction and complete elimination of high temperature induced defects such as cell warpage occasionally associated with existing processes. In SOFC technology, nickel aids fuel catalysation and electronic conductivity while YSZ in addition to preventing nickel from sintering at high SOFC operating temperatures of about $1000^{\circ} \mathrm{C}$, re- lieves the coefficient of thermal expansion (CTE) mismatch between the anode and electrolyte [8,9,10] (nickel $-13 \times$ $\left.10^{-6} /{ }^{\circ} \mathrm{C} \& \mathrm{YSZ}-10 \times 10^{-6} /{ }^{\circ} \mathrm{C}\right)$. High nickel content promotes cell cracking while too low a content and correspondingly high YSZ presence could compromise cell efficiency and performance [11]. To avoid unwanted occurrences such as cell de-lamination which may arise due to CTE mismatch, an understanding of the structure of ceramic to metal ratios obtained by ECD or the effect of additives that may aid achievement of a desired 60 40 composition is essential. In fact for use of ECD deposits as intermediate layers in thermal barrier coatings (TBC) where material insulation in high temperature environments is sought, the required proportion of ceramic to metal is even greater.

Surfactants, non-ionic (steric stabilised) or anionic, cationic and zwitter ionic (electrostatic interaction) are 
surface active agents that in addition to lowering the surface tension of a liquid also allow for easy spreading and less interfacial tension between two liquids. Its inherent amphiphilic property that arises due to its molecules dual lyophobic-lyophilic tendency, has been previously employed for dispersion of ceramic powders in polymers $[12,13]$ and polymers in solutions including electroless nickel [14]. While Wu, et al. [15] used sodium dodecyl sulphate (SDS) to increase the wettability and dispersion of silicon carbide particles, Elansezhian, et al. [16] performed studies on Ni-P coatings influenced by anionic and cationic surfactants SDS and cetyltrimethyl ammonium bromide (CTAB). They reported that the concentration of surfactant utilised in the process had an effect on the surface morphology of the deposits. Hardness of the coatings was found to progressively increase with SDS content while surface roughness reduced as the level of surfactant reached $0.6 \mathrm{~g} / \mathrm{l}$. The resultant smooth surface was attributed to uniform dispersion of fine nickel particles. While their observation is in line with the findings of Tripathy, et al. [17] who studied the effect of sodium lauryl sulphate on zinc electrowinning from acidic sulfate solutions, Karuppusamy \& Anantharam [18] also reported that addition of 150ppm SDS resulted in uniform and pit free nickel deposits.

In this work, the influence of SDS on the composition of nickel-YSZ coatings applied by ECD process is investigated. Associated changes in the characteristics of the coatings such as thickness is also assessed and reported.

\section{Experimental}

\subsection{Procedure}

Alumina $\left(\mathrm{Al}_{2} \mathrm{O}_{3}\right)$ tiles, $40 \times 15 \times 1 \mathrm{~mm}$ were used as substrates for the deposition. Overcoming the insulation posed by such ceramic surfaces was achieved via pretreatment processes. Cuprolite X-96 DP (2-Aminoethanols $(1 \%-4 \%))$ (Alfachimici, Italy), was employed at $60^{\circ} \mathrm{C}$ for 15 mins to degrease the substrate's surface. Next, to sensitise the surface, the substrate was immersed in $100 \mathrm{ml}$ of stannous chloride solution at room temperature for 15 mins. The final step performed for surface activation was carried out in a solution containing palladium chloride with temperature ranging between $36^{\circ} \mathrm{C}$ to $40^{\circ} \mathrm{C}$.

Electroless nickel solution for the deposition process was made up from proprietary slotonip 18 - 51 starter and slotonip 18 - 53 replenisher chemicals supplied by Schloetter company limited. Bath $\mathrm{pH}$ and plating temperature were 4.9 and $89^{\circ} \mathrm{C}$ respectively. SDS (Fisher Scientific, UK) and yttria stabilised zirconia (YSZ) (Unitec Inc.) were added to the bath prior to the introduction of the pre-treated alumina tile. A magnetic stirrer was used to ensure particle dispersion and deposition time was $1 \mathrm{hr}$. Governing reactions are as detailed by Gutzeit [19] in Equations 1-4.

$$
\begin{gathered}
\left(\mathrm{H}_{2} \mathrm{PO}_{2}\right)^{-}+\mathrm{H}_{2} \mathrm{O} \rightarrow\left(\mathrm{H}_{2} \mathrm{PO}_{3}\right)^{-}+2 \mathrm{H}^{+}+2 \mathrm{e}^{-} \\
\mathrm{Ni}^{2+}+2 \mathrm{e}^{-} \rightarrow \mathrm{Ni} \\
2 \mathrm{H}+2 \mathrm{e}^{-} \rightarrow \mathrm{H}_{2} \\
\left(\mathrm{H}_{2} \mathrm{PO}_{2}\right)^{-}+2 \mathrm{H}^{+}+\mathrm{e}^{-} \rightarrow \mathrm{P}+2 \mathrm{H}_{2} \mathrm{O}
\end{gathered}
$$

Electrons from the hypophosphite ion reduce nickel ions to nickel metal (1) \& (2). The nickel metal thereafter entraps YSZ particles while adsorbing on the activated alumina substrate.

Unfortunately, phosphorus, a resultant element simultaneously produced from the hypophosphite ion (4), poses a challenge in fuel cell technology. Besides being noted to have a characteristic property of reducing the anode/cell performance [20,21], phosphorus has a tendency to form a liquid phase with nickel at temperatures above $850^{\circ} \mathrm{C}$ which thereafter precipitation hardens to yield an undesired material, nickel phosphide $\left(\mathrm{Ni}_{3} \mathrm{P}\right)$. Alternatives such as hydrazine $\left(\mathrm{N}_{2} \mathrm{H}_{4}\right)$-probably with less deleterious effects-do exist, but have considerable cost implications.

\subsection{Sample Preparation and Characterisation}

A Struers Accutom-5 precision cutter was used to cut cross-sections of the coated substrate. The feed rate was set at $0.02 \mathrm{~mm} / \mathrm{s}$ and the utilised diamond tip cutting disc was maintained at a speed of $3000 \mathrm{rpm}$. The samples were thereafter mounted in $40 \mathrm{~mm}$ diameter epoxy resin and grinding and polishing was carried out with the aid of the TegraForce-5/TegraPol-21. Contact force for both operations was $50 \mathrm{~N}$ with an anti-clockwise rotation of $150 \mathrm{rpm}$.

The surface structure of the coatings was observed with a Cambridge Stereoscan 90 Scanning Electron Microscope (SEM) while an in-situ Oxford Instrument Inca Energy Dispersive X-ray Analysis system (EDXA) was relied upon for analysis of its composition. For examination of the thickness and characteristics of the coatings, a Leitz Aristomet Hi-power light microscope was employed.

All experiments were repeated twice and an average of both results is reported.

\section{Results and Discussion}

\subsection{Pre-surfactant Ceramic Loading}

Prior to the introduction of SDS, the optimum pre-surfactant YSZ concentration for maximum incorporation of 
the ceramic into the nickel matrix was sought. Evaluation of ECD coatings for selected YSZ bath loadings of $0 \mathrm{~g} / \mathrm{l}$, $10 \mathrm{~g} / \mathrm{l}, 50 \mathrm{~g} / \mathrm{l}$ and $100 \mathrm{~g} / \mathrm{l}$ was carried out to estimate this value.

Light microscopy images revealed that, with increasing YSZ loading in the bath, the uniform surface finish generally associated with ENP processes, gradually became uneven (Figure 1). Visually, the coatings changed colour from shiny metallic silver to dark black-an observation probably due to reduced metal exposure which resulted in lower light reflection from the surface of the coating.

On assessment of coating thicknesses achieved, an inverse relationship was found to exist between the plating thickness and level of YSZ loading in the bath (Figure 2). As un-activated co-deposited YSZ particles provide insulating less reactive facets, that do not encourage autocatalytic deposition of nickel metal continuously reduced from its ions, increase in YSZ loading may have resulted in growth retardation of the deposit layer. In fact, examination of coatings carried out with $100 \mathrm{~g} / \mathrm{l} \mathrm{YSZ}$ bath loading, which showed a thickness of only about 2 $\mu \mathrm{m}$, is evidence that the YSZ powder formed an almost complete barrier to nickel adsorption on the surface. Sheela and Pushpavanam [5] who studied electroless nickel-diamond coatings and Balaraju, et al. [22] who investigated electroless Ni-P composite coatings also observed a similar trend. The latter suggests that the emergent pattern could be ascribed to the possibility of grouping or agglomeration of second phase particles resulting

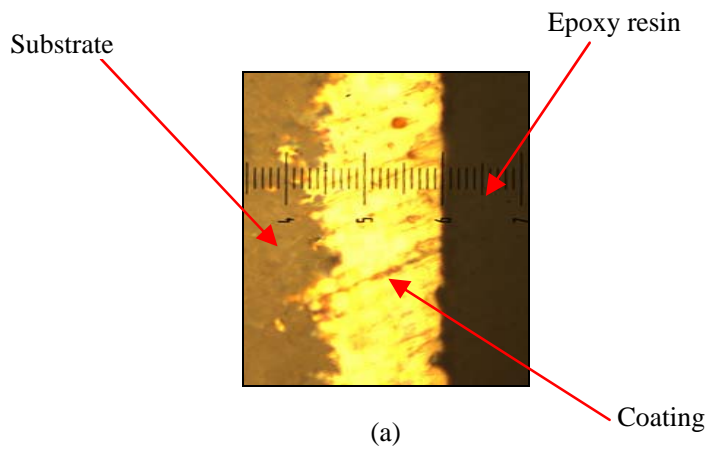

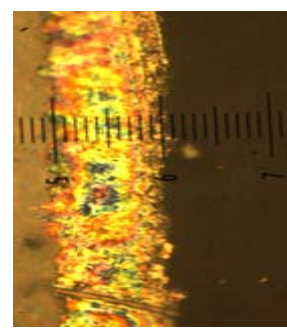

(b)

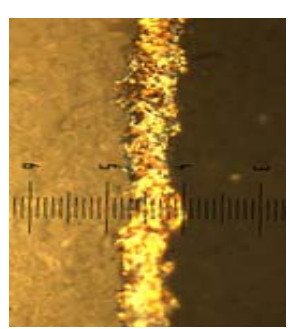

(c)
Figure 1. Photo micrographs showing the cross sectional view of nickel-YSZ coatings (a) No ceramic loading (b) 10 $\mathrm{g} / \mathrm{l}$ and (c) $50 \mathrm{~g} / \mathrm{l}$ (×500 mag).

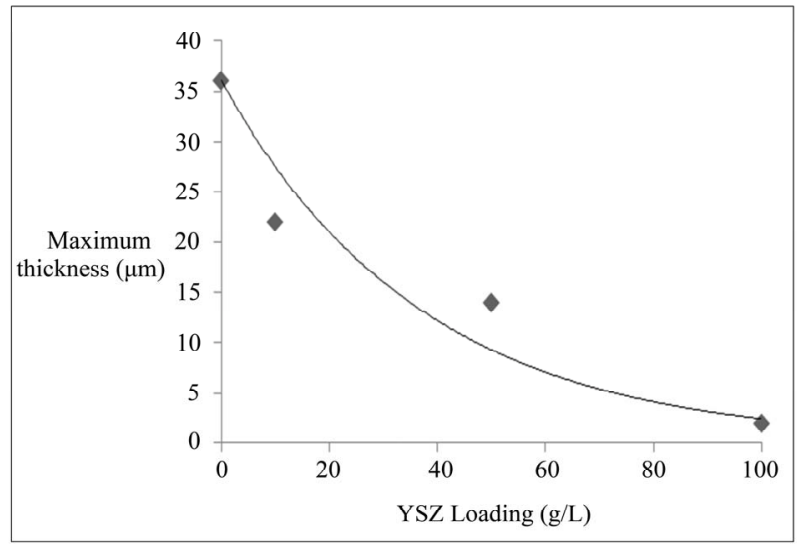

Figure 2. Coating thickness vs $5 \mu \mathrm{m}$ particle size YSZ bath loading.

from a decrease in the mean distance between them.

EDXA analysis of the coatings showed that maximum incorporation of YSZ particles occurred at $50 \mathrm{~g} / \mathrm{l}$ with a ceramic to metal ratio of about 40:60 volume\% (Figure 3 ). As this value was found to vary with the maximum 30 volume\% ceramic content of electroless nickel composite coatings reported by Baba, et al. [23] and Dini [24], the resultant higher ceramic ratio may be related to a different particle size used or bath composition adopted. Further increases beyond the $50 \mathrm{~g} / \mathrm{l}$ YSZ loading however yielded no increased ceramic content.

\subsection{SDS Incorporation}

Based on the results obtained, $50 \mathrm{~g} / \mathrm{l} \mathrm{YSZ}$ loading was adopted for the surfactant study. YSZ powders of $1 \mu \mathrm{m}$ and $5 \mu \mathrm{m}$ average particle sizes were utilised with SDS concentration varied from 0 to $0.9 \mathrm{~g} / \mathrm{l}$.

With bath parameters held constant, it was observed

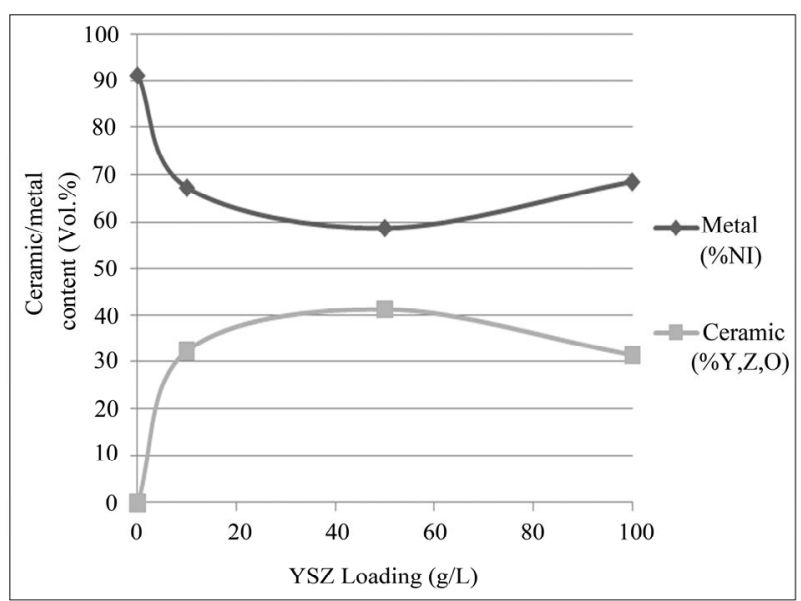

Figure 3. Ceramic (Y, Z, O) and metal (Ni) content of $5 \mu \mathrm{m}$ YSZ particle size loading. 
that the coatings became incoherent as SDS concentration increased. This occurrence which probably indicates improper or obstructed nickel adherence to the substrate, may be linked with the findings by Ger \& Hwang [14] who while attempting to improve the mechanical and tribological properties of Ni-P deposits, employed the cationic surfactant fluorinated alkyl quaternary ammonium iodides (FC) to aid incorporation of polytetraflouroethylene particles into the nickel matrix. The authors who noted a reduction in nickel's rate of deposition as the quantity of surfactant increased suggest that, the behaviour can be associated with increased adsorption of the surfactant on the substrates surface which thereof acts as a barrier to deposition.

Increase in the level of SDS appeared to have a greater impact on the characteristics of platings carried out with 1 $\mu \mathrm{m}$ YSZ particles than the $5 \mu \mathrm{m}$ sizes. While the latter maintained almost the same features pre- and post- SDS (Figures 4(a) and 5(a)), the former witnessed higher incorporation of ceramic particles (Figure 4(b)) but at the expense of coating thickness which experienced a drastic reduction from about $14 \mu \mathrm{m}$ to $2 \mu \mathrm{m}$ (Figure 5(b)). Corresponding EDXA spectra (Figure 6) of SDS incorporated

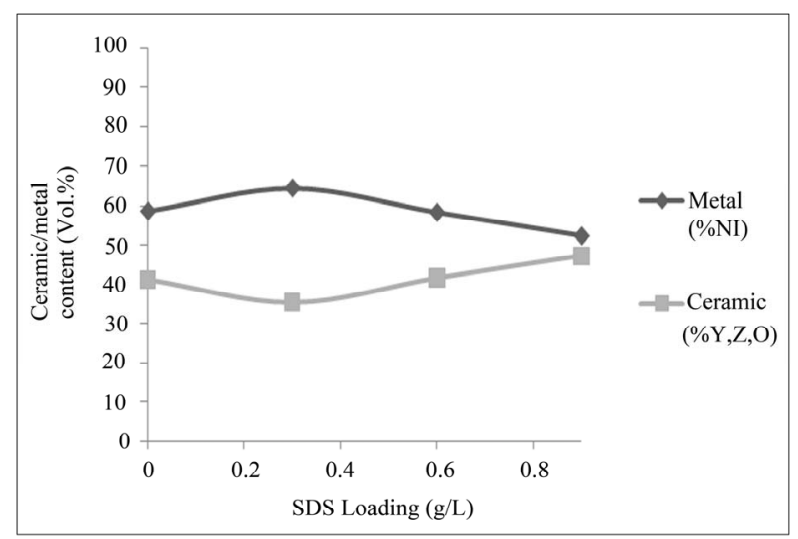

(a)

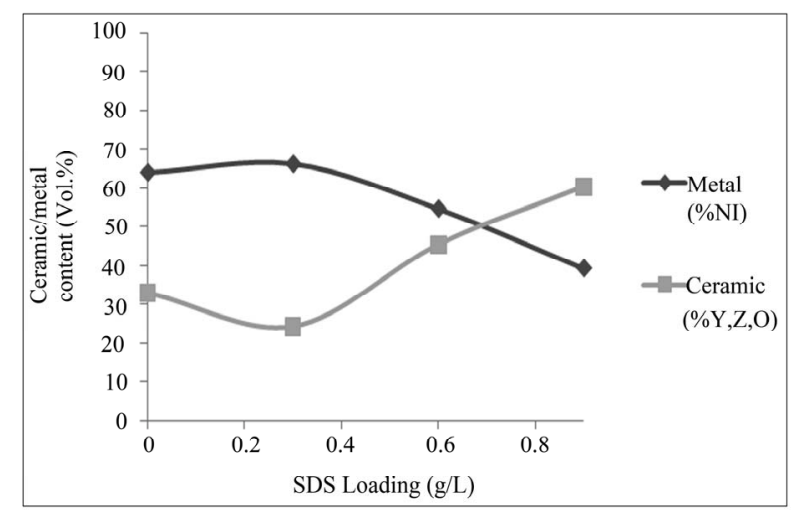

(b)

Figure 4. Influence of SDS on the ceramic to metal content of $50 \mathrm{~g} / \mathrm{l}$ (a) $5 \mu \mathrm{m} \&$ (b) $1 \mu \mathrm{m}$ YSZ particle size coatings.

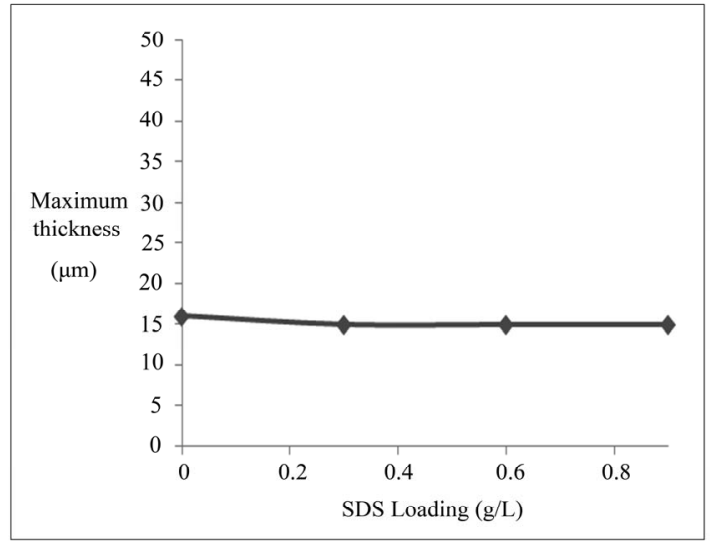

(a)

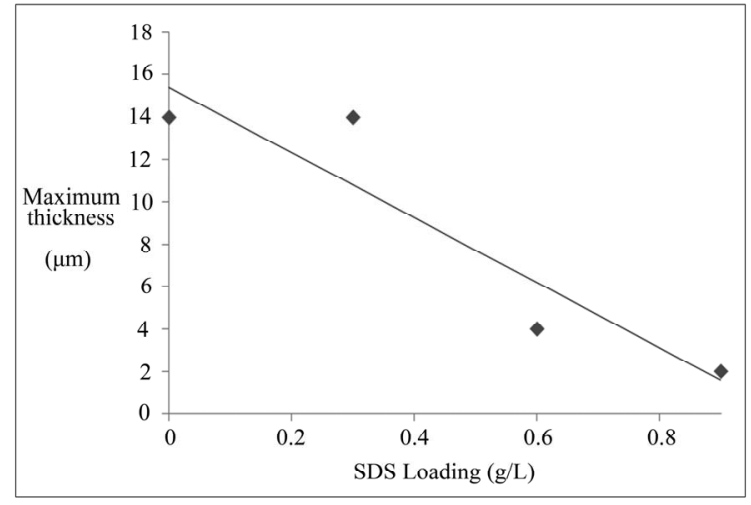

(b)

Figure 5. Influence of SDS on the thickness of nickel-(a) 5 $\mu \mathrm{m} \&$ (b) 1 um YSZ particle size coatings.

$1 \mu \mathrm{m}$ YSZ particle coatings, which shows increasing peaks of Yttrium, Zirconium and Oxygen, and the decreasing peaks of nickel, further illustrates the observed increase in ceramic content. Working with the surfactant 1179 Forafac (trade name for similar FC surfactant used in [14]), Grosjean, et al. [25] also observed a similar trend. The authors reported that when 500ppm FC was added to the bath, incorporation of silicon carbide particles rose from 19 to 53 volume \%.

An inspection of both ceramic to metal ratio plots (Figure 4) though showed that on addition of $0.3 \mathrm{~g} / \mathrm{l}$ SDS, an increase in the nickel content of both $5 \mu \mathrm{m}$ and $1 \mu \mathrm{m}$ YSZ particle size coatings occurred. But as the concentration of SDS in the bath increased, the metal content of both particle size coatings was found to decrease. This behaviour maybe akin to the varying critical micelle concentration (CMC) of SDS in different solutions. Newberry [26], Muijselaar, et al. [27] and Su, et al. [28], have all shown via various studies that the CMC of SDS in divalent metal solutions is far less than its usual 8 $\times 10^{-3} \mathrm{M}$ in pure water being $4 \times 10^{-3} \mathrm{M}$ for nickel and 2 $\times 10^{-3} \mathrm{M}$ for copper depending on concentration. As $4 \times$ $10^{-3} \mathrm{M}$ corresponds to $0.6 \mathrm{~g} / \mathrm{l} \mathrm{SDS}$ content, it can be in 


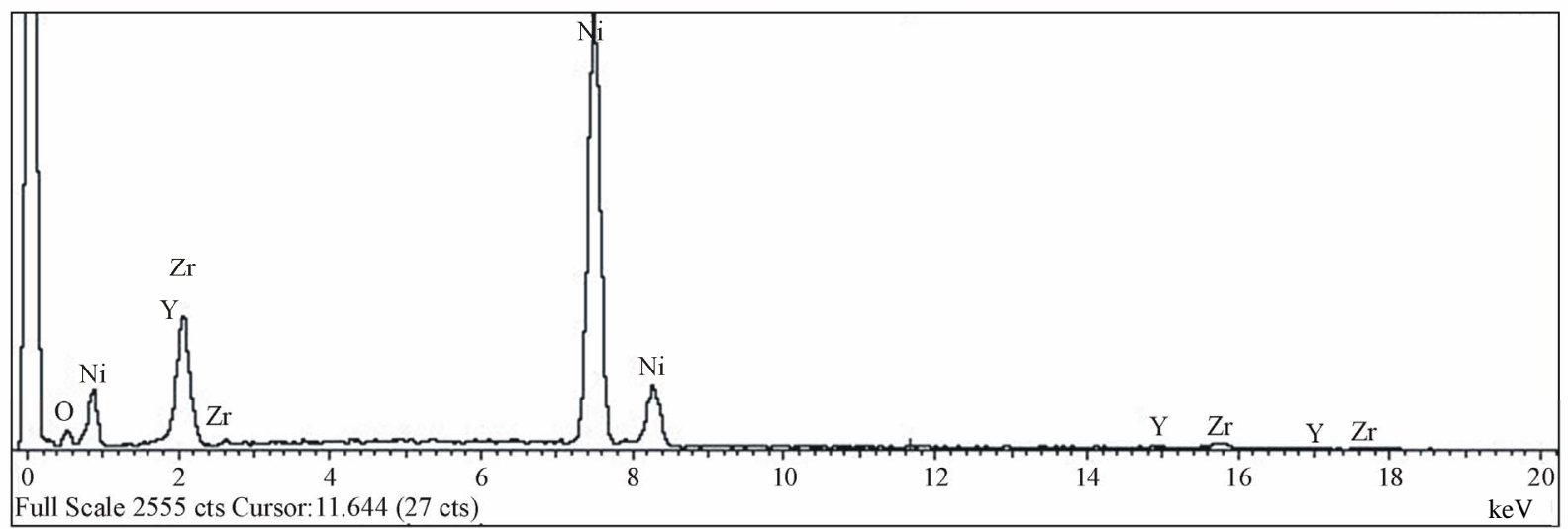

(a)

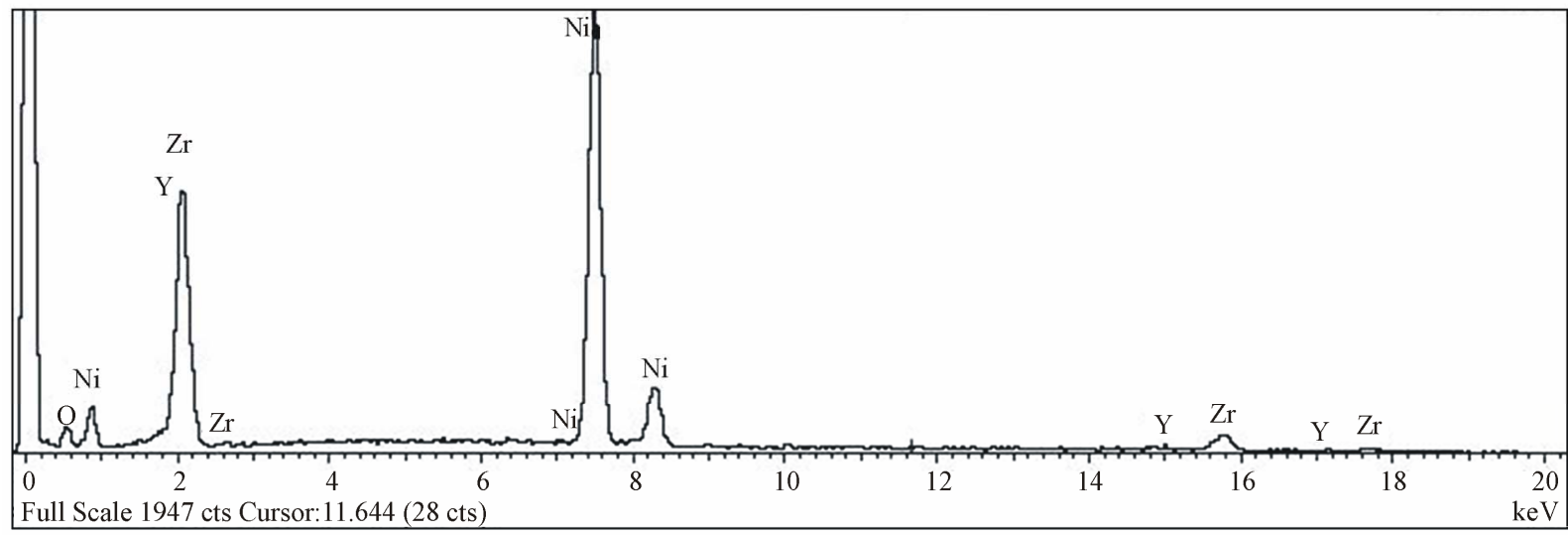

(b)

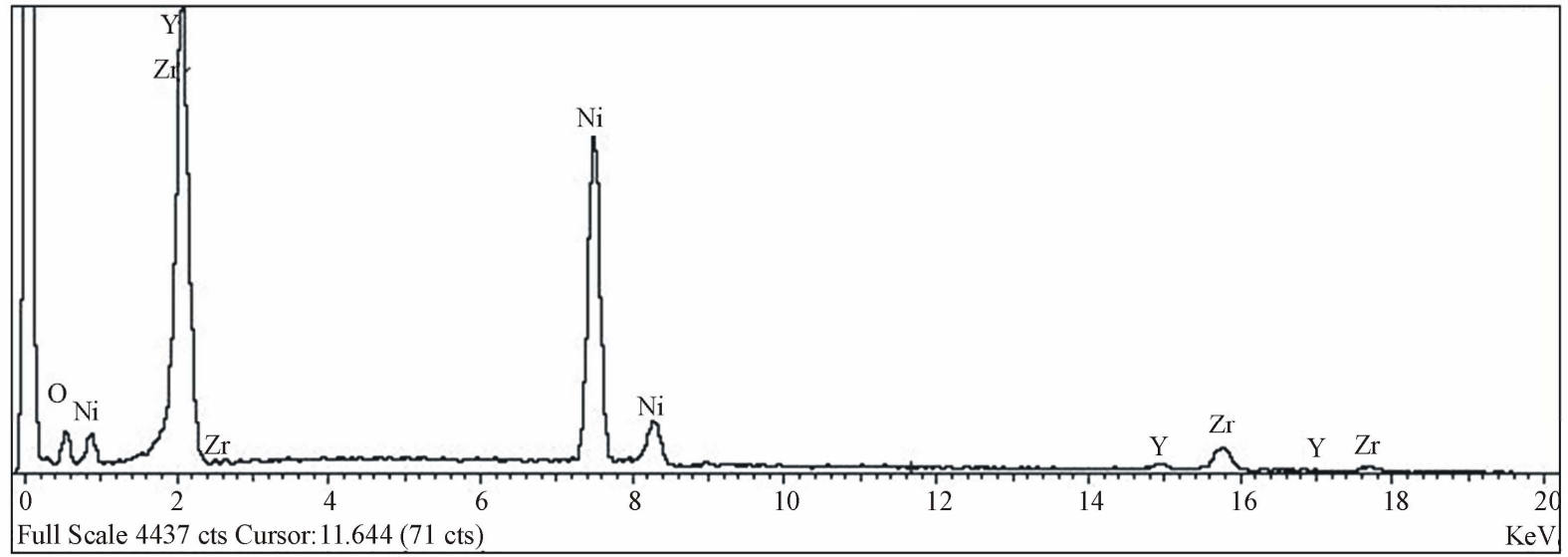

(c)

Figure 6. Energy Dispersive X-ray spectra of (a) 0.3 g/l (b) 0.6 g/l (c) 0.9 g/l SDS incorporated Ni-YSZ coatings.

ferred that the attained CMC enhanced YSZ particle dispersion which yielded an increased level of ceramic incorporation in the coating.

Examination of SEM micrographs (Figure 7) appear to suggest that surface roughness of the coatings increased with SDS content-an observation consistent with the report by Alsari, et al. [29]. While investigating the effect of SDS solutions as gelation media on the for- mation of polyethersulfone (PES) membranes, the authors noted that upon SDS attaining its CMC, the consequential increase in pore size resulted in increased roughness of the membranes.

\section{Conclusions}

The effect of the surfactant SDS on the composition of 


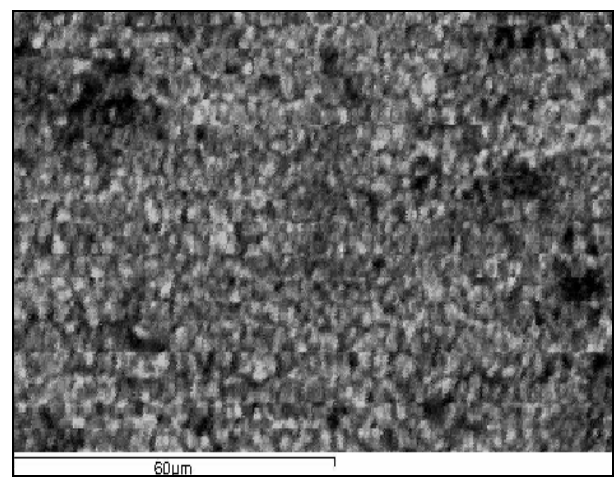

(a)

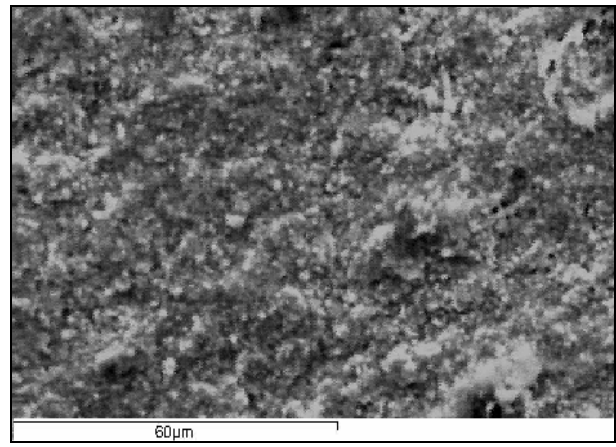

(b)

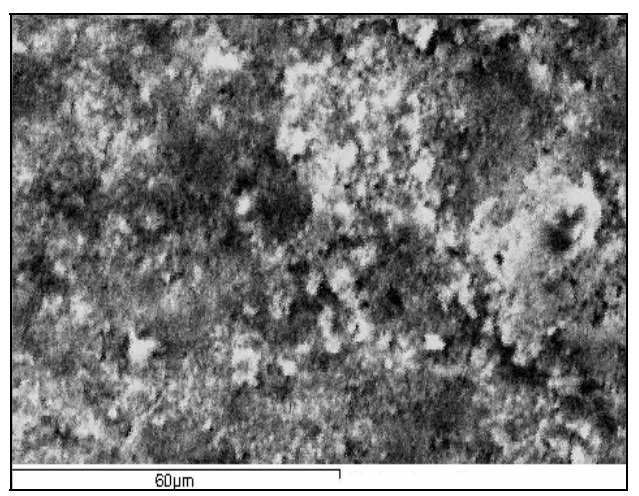

(c)

Figure 7. SEM images of (a) $0.3 \mathrm{~g} / \mathrm{l}$ (b) $0.6 \mathrm{~g} / \mathrm{l}$ (c) $0.9 \mathrm{~g} / \mathrm{l}$ SDS incorporated $50 \mathrm{~g} / \mathrm{l}$ YSZ loading/1 $\mu \mathrm{m}$ particle size coatings $\times 1,000$ mag.

nickel-YSZ ECD composite coatings, has been investigated and reported.

Results obtained show that, by adding SDS to an elec-troless nickel bath containing a pre-determined optimum YSZ loading of $50 \mathrm{~g} / \mathrm{l}$, up to 60 volume\% YSZ can be incorporated into cermet coatings applied by ECD. A trade-off though was observed with increasing SDS content as plating thickness decreased from $14 \mu \mathrm{m}$ to about 2 $\mu \mathrm{m}$ and the coatings became incoherent. Inspection of the surfaces via micrographs obtained by SEM appeared to support the fact that surface roughness also increased with SDS concentration.
Overall, the achievement of 60:40 ceramic to metal ratio may suggest, existence of materials that may be incorporated to enhance the ceramic content of SOFC electrodes synthesised by ECD. However, with a relatively high metal content still present, further optimisation may be needed to adapt the process to technologies such as thermal barrier coatings.

\section{References}

[1] G. O. Mallory and J. B. Hajdu, "Electroless Plating: Fundamentals and Applications," William Andrew Publishing, Burlington, 1990.

[2] A. Brenner and G. Riddel, "Nickel Plating on Steel by Chemical Reduction,” US Patent 2532282, 1950.

[3] R. C. Agarwala and V. Agarwala, "Electroless Alloy/Composite Coatings: A Review,” Sadhana, Vol. 28, No. 3-4, 2003, pp. 475-493. doi:10.1007/BF02706445

[4] J. M. Odekerken, "Use of Co-deposited Non-conducting Materials to Improve the Corrosion Resistance of NickelChromium Electrodeposits,” British Patent 1041753, U.S. Patent 3644183 and DDR Patent 414061964.

[5] G. Sheela and M. Pushpavanam, "Diamond-Dispersed Electroless Nickel Coatings,” Journal of Metal finishing, Vol. 100, No. 1, 2002, pp. 45-47.

[6] A. Davidson and W. Waugh, "Method of Manufacture of an Electrode for a Fuel Cell," World intellectual Property Organisation Patent No. O/2009/044144, 2009.

[7] N. Nwosu, A. Davidson and W. Waugh, "Characterisation of Solid Oxide Fuel Cell Cathodes Manufactured by Traditional and Novel (Low Cost) Techniques,” Proceedings of the First International Conference on Materials for Energy, Karlsruhe, 4-8 July 2010, pp. 81-85.

[8] J. Mizusaki, S. Tsuchiya, K. Waragai, H. Tagawa, A. Yoshihidi and Y. Kuwayama, "Simple Mathematical Model for the Electrical Conductivity of Highly Porous Ceramics,” Journal of American Ceramic Society, Vol. 79, No. 1, 1996, pp. 109-113.

doi:10.1111/j.1151-2916.1996.tb07887.x

[9] W. Dees, T. D. Claar, T. E. Easler, D. C. Fee and F. C. Mrazek, "Conductivity of Porous $\mathrm{Ni} / \mathrm{ZrO}_{2}-\mathrm{Y}_{2} \mathrm{O}_{3}$ Cermets," Journal of Electrochemical Society, Vol. 134, No. 9, 1987, pp. 2141-2146. doi:10.1149/1.2100839

[10] T. Iwata, "Characterization of Ni-YSZ Anode Degradation for Substrate-Type Solid Oxide Fuel Cells,” Journal of Electrochemical Society, Vol. 143, No. 5, 1996, pp. 15211525. doi:10.1149/1.1836673

[11] R. Bauri, "Development of Ni-YSZ Cermet Anode for Solid Oxide Fuel Cells by Electroless Ni Coating,” Journal of Coating Technology and Research, 2009. doi:10.1007/s11998-009-9223-z

[12] Y. Rao, A. Takahashi and C. P. Wong, "Di-block Copolymer Surfactant Study to Optimize Filler Dispersion in High Dielectric Constant Polymer-Ceramic Composite," Journal of Composites Part A: Applied Science and Manu- 
facturing, Vol. 34, No. 11, 2003, pp. 1113-1116. doi:10.1016/S1359-835X(03)00202-1

[13] L. Gabrieson and M. J. Edirisinghe, "On the Dispersion of Fine Ceramic Powders in Polymers,” Journal of Materials Science Letters, Vol. 15, No. 13, 1996, pp. 1105-1107. doi:10.1007/BF00539950

[14] M.-D. Ger and B. J. Hwang, "Effect of Surfactants on Co-deposition of PTFE Particles with Electroless Ni-P Coating," Materials Chemistry and Physics, Vol. 76, No. 1, 2002, pp. 38-45. doi:10.1016/S0254-0584(01)00513-2

[15] Y. C. Wu, G. H., Li L. Zhang and B. Yan, "Study on Constitution and Wear Resistance of Nickel Phosphorus Alloy-Silicon Carbide Composite Coatings,” Materials Research and Advanced Techniques, Vol. 91, 2000, pp. 788-793.

[16] R. Elansezhian, B. Ramamoorthy and P. K. Nair, "The Influence of SDS and CTAB Surfactants on the Surface Morphology and Surface Topography of Electroless Ni-P Deposits,” Journal of Materials Processing Technology, Vol. 209, No. 1, 2009, pp. 33-240. doi:10.1016/j.jmatprotec.2008.01.057

[17] B. C. Tripathy, S. C. Das., G. T. Hefter and P. Singh, "Electro Winning from Acidic Sulphate Solution. Part 1. Effects of SLS,” Journal of Applied Electrochemistry, Vol. 27, No. 6, 1997, pp. 673-674. doi:10.1023/A:1018431619595

[18] K. Karuppusamy and R. Anantharam, "Pit-Free Nickel Electroplating,” Metal finishing, Vol. 90, No. 13, 1992, pp. 15-19.

[19] G. Gutzeit, "Catalytic Nickel Deposition from Aqueous Solution. I-IV,” Plating surface finishing, Vol. 46, 1959, pp. 1158-1164, 1275-1278, 1377-1378.

[20] K. Haga, Y. Shiraton, Y. Nojiri, K. Ito and K. Sasaki, "Phosphorus Poisoning of Ni-Cermet Anodes in Solid Oxide Fuel Cells,” Journal of Electrochemical Society, Vol. 157, No. 11, 2010, pp. 1693-1700. doi:10.1149/1.3489265
[21] A. Tsoga, A. Naoumidis and P. Nikolopoulos, "Wettability and Interfacial Reactions in the Systems Ni/YSZ and Ni/Ti-TiO 2 /YSZ,” Acta Materialia, Vol. 44, No. 9, 1996, pp. 3679-3692. doi:10.1016/1359-6454(96)00019-5

[22] J. N. Balaraju, T. S. N. S. Narayanan and S. K. Seshadri, "Electroless Ni-P Composite Coatings," Journal of Applied Electrochemistry, Vol. 33, No. 9, 2003, pp. 807 -816. doi:10.1016/1359-6454(96)00019-5

[23] N. B. Baba, W. Waugh and A. Davidson, "Manufacture of Electroless Nickel/YSZ Composite Coatings," Proceedings of World Academy of Science, Engineering and Technology, Vol. 49, 2009, pp. 715-720.

[24] J. W. Dini, "Electrodeposition: The Materials Science of Coatings and Substrates," William Andrew Publishing, Noyes, 1993, p. 336.

[25] A. Grosjean, M. Rezrazi and M. Tachez, "Study of the Surface Charge of Silicon Carbide (SIC) Particles for Electroless Composite Deposits: Nickel-SIC," Surface and Coating technology, Vol. 96, No. 2-3, 1997, pp. 300304.

[26] J. E. Newberry, "Surface Interactions of Micelles and Divalent Metal Ions,” Journal of Colloid and Interface Science, Vol. 74, No. 2, 1979, pp. 483-488. doi:10.1016/0021-9797(80)90217-9

[27] P. G. Muijselaar, K. Otsuka and S. Terabe, "Micelles as Pseudo-Stationary Phases in Micellar Electrokinetic Chromatography,” Journal of Chromatography, Vol. 780, No. 1, 1997, pp. 41-61. doi:10.1016/S0021-9673(97)00632-8

[28] S. Su, Y. L. Chen and C. Y. Mou, "Micelle-Counterion Interaction, I. Critical Micelle Concentrations of SDS under the Influence of Copper Counterion," Journal of Chinese Chemical Society, Vol. 32, No. 1, 1985, pp. 5-10.

[29] A. M. Alsari, K. C. Khulbe and T. Matsuura, "The Effect of Sodium Dodecyl Sulfate Solutions as Gelation Media on the Formation of PES Membranes," Journal of Membrane Science, Vol. 188, No. 2, 2001, pp. 279-293. doi:10.1016/S0376-7388(01)00395-7 